ISSN 2078-6441. Вісник Львівського університету. Серія географічна. 2013. Випуск 42. С. 298-305. Visnyk of the Lviv University. Series Geography. 2013. Issue 42. P. 298-305.

911:502.5

\author{
вло ом нів, ндрій нько \\ ьвівський н ціон льний університет імені в н \\ вул. . орошенк , 41, 79000, м. ввів, кр їн
}

ростежено ф ктори розвитку туристичної г лузі утильського р-ну ернівецької обл. осліджено туристичні ресурси, інфр структуру, м тері льно-технічну б зу р йону для потреб розвитку туризму. иявлено вплив природно-геогр фічних, історико-культурних, соці льноекономічних умов т ф кторів, що потенційно т кту льно вплив ють н формув ння регіон льного туристичного продукту досліджув ного $\mathrm{p}$ йону. ростежено чинники, що лімітують розвиток туризму у р йоні, зокрем , низький рівень розвитку рекре ційно-туристичної інфр структури т недост тність методичної, орг ніз ційної, інформ ційної підтримки суб'єктів туристичної діяльності.

лючові слов : утильський р-н, туристичні ресурси, інфр структур , орг ніз ція туризму.

роблем туристично-рекре ційного освоєння регіонів первинно передб ч є моніторинг кту льних ресурсів, елементів інфр структури, м тері льно-технічної б зи тощо, які потенційно можуть ст ти передумов ми розвитку туристично-рекре ційної діяльності. розуміло, що н явність ресурсів (природних, історико-культурних), первинних інфр структурних елементів без ур хув ння внутрішніх т зовнішніх чинників середовищ не приведе до виникнення туристичної г лузі як конкурентоспроможного елемент регіон льної економіки. ме тому н ш мет - про н лізув ти ресурсну т інфр структурну н повненість утильського р-ну ернівецької обл., простежити головні чинники розвитку туристичного господ рств $\mathrm{p}$ йону.

ослідженню проблем і перспектив розвитку туристичної г лузі в ернівецькій обл. присвячені пр ці б г тьох н уковців, зокрем . ифяк , . уднікевич , . урилюк, . ерд нцевої, . вдокименко, . ілінської т ін. роблем м регіон льної рекре ційно-туристичної політики рп тського регіону кр їни з г лом присвячені пр ці . вдокименк, . р вців, . узик . риродно-ресурсний потенці л кр їни, iii дміністр тивних одиниць досліджено у пр цях . уденк, історико-культурний туристичний потенці л - у пр цях . нилюк .

утильський р-н з йм є південно-з хідну ч стину ернівецької обл. півдні проходить держ вний кордон 3 умунією, н 3 ході - меж 3 ерховинським р-ном в ноp нківської обл., н сході - 3 ижницьким р-ном ернівецької обл. лизько $63 \%$ території р йону покрито ліс ми, де п нівними пород ми $є$ ялин, смерек т бук звич йний. $\quad$ х р ктером рельєфу більшість території р йону - гірськ ч стин . ут $€$ н йвищі вершини уковинських рп т - гори ровиця (1 574 м), уп ни (1 $488 \mathrm{M})$, орний іл (1 452 м). p йоні густ гідрогр фічн мереж : орний і ілий еремош, утилк, р т, уч в .

(C) ом нів ., нько ., 2013 
ля розвитку утильського р-ну, його внутрішньорегіон льного т н ціон льного позиціонув ння пріоритетним, н н ш погляд, є освоєння пізн в льно-туристичного потенці лу, про що свідчить низк ргументів:

- н явність необхідної природно-ресурсної б зи, кту льно т потенційно використовув ної для пізн в льно-туристичних цілей;

- могутній потенці л для розвитку різних видів туризму (зн чн л ндш фтн різном нітність, б г те історичне минуле);

- порівняно вигідне економіко-геогр фічне, геополітичне, тр нспортногеогр фічне положення ( утильський р-н як ч стин рп тського регіону розміщений у центрі вропи);

- чинник територі льного поділу пр ці (умови д ють змогу з безпечув ти з доволення суспільних потреб у рекре ційно-туристичних послуг х);

- порівняно висок екологічн безпек регіону;

- соці льно-економічн специфік гірських р йонів (гори створюють специфічні, н дзвич йно скл дні умови для прожив ння і господ рюв ння, тому тут н дзвич йно гостр проблем з йнятості і, як н слідок, низький рівень м тері льного добробуту жителів гір, що спонук є до пошуку джерел з йнятості т доходів місцевого н селення);

- економічн конкурентоспроможність туристично-рекре ційної сфери рп тського регіону кр їни $[2,3]$.

контексті розвитку туризму в регіоні виділимо структурні скл дові туристичнорекре ційного потенці лу, який репрезентуємо через призму т ких компонентів: природно-клім тичні компоненти, культурно-історичні ресурси (культурно-історичн сп дщин , твори мистецтв , рхеологічні цінності, тр диції, етнос із його полікультурним н дб нням), інфр структур т м тері льно-технічн 63 . ричому інфр структуру треб розгляд ти як комплекс споруд і мереж, які з безпечують норм льний доступ туристів до туристичних ресурсів 3 для їхнього н лежного використ ння в цілях туризму т рекре ції.

утильський р-н м є зн чні відмінності від інших регіонів кр їни у турпродуктному н повненні. ля цілей пізн в льного туризму ресурси кр їнських рп т з г лом можн розділити н дві великі групи:

- природні ресурси;

- історико-етнокультурні ресурси.

риродні ресурси - це ресурси н вколишнього середовищ з мережею сільських поселень, н явними природними об'єкт ми, явищ ми, процес ми (гідрологічні, геоморфологічні, геобот нічні, клім тичні), що кту льно т потенційно м ють туристично-рекре ційне н в нт ження (див. т бл. 1,2), т ре л ми м лозмінених людиною природних екосистем (передусім об'єкти природно-з повідного фонду). сторико-етнокультурні ресурси - це об'єкти т явищ м тері льної і духовної культури життєдіяльності етносу н території його історичного розвитку. о цього виду ресурсів н леж ть п м'ятки історії, м тері льної етнокультури (тр диційне гуцульське житло, млини, колиби, продукція н родних ремесел (ліжники, кер мік , різьб по дереву, вироби з лози тощо)), с кр льної рхітектури (мон стирі, церкви, к плиці, ст рожитні п м'ятні хрести тощо), духовної етнокультури (побутові т культові обряди й н родні тр диції) $[1,4]$, т кож фестив лі.

погляду дестин ції утильський р-н - це регіон б г топрофільного літнього і зимового відпочинку, гірсько-спортивного і м сового оздоровчого відпочинку т 6 льнеологічного лікув ння. 
лощ рекре ційних територій утильського р-ну, г

блиця 1

(з д ними р йонного упр вління охорони н вколишнього природного середовищ )

\begin{tabular}{|c|c|c|}
\hline \multicolumn{2}{|c|}{ ок зник } & \multicolumn{2}{|c|}{ гіддя } \\
\cline { 2 - 3 } & іси & уки \\
\hline г льн площ м ло змінених угідь, г & 21938 & 15017 \\
\hline $\begin{array}{c}\text { лощ угідь, прид тних для рекре ційного } \\
\text { використ ння, г }\end{array}$ & 18031 & 12225 \\
\hline
\end{tabular}

екре ційно-ємнісний потенці л утильського р-ну, осіб/день

блиця 2

(з д ними р йонного упр вління охорони н вколишнього природного середовищ )

\begin{tabular}{|c|c|c|}
\hline \multirow[t]{2}{*}{ ок Зник } & \multicolumn{2}{|c|}{$\begin{array}{cl}\text { ксим льн } \\
\text { рекре ційн ємність, } \\
\text { осіб/день }\end{array}$} \\
\hline & іси & уки \\
\hline $\begin{array}{c}\text { ксим льн рекре ційн ємність, } \\
\text { осіб/день }\end{array}$ & 46284 & 28144 \\
\hline $\begin{array}{c}\text { екре ційн ємність угідь для м сового } \\
\text { відпочинку, осіб/день }\end{array}$ & 27770 & 16886 \\
\hline $\begin{array}{c}\text { екре ційн } \\
\text { ємність угідь для туризму, } \\
\text { осіб/день }\end{array}$ & 11571 & 7036 \\
\hline
\end{tabular}

утильському р-ні зосереджено чим ло історико-культурних п м'яток, проте вони відрізняються між собою як художньо-мистецькою, т к і пізн в льною цінністю.

сновними поселеннями, які м ють історико-культурні туристичні ресурси, $€$ утил, ідз х ричі, ихтинець, сть- утил, озтоки, елятин, епіт т ін.

йприв бливішими місцями утильських рп тє п м'ятки рхітектури, історичні п м’ятки, музеї, з повідні об'єкти. ведемо прикл ди деяких з них.

$$
\text { м'ятки рхітектури }
$$

1. утил - церкв св. икол я т дзвіниця (1885).

2. ихтинець-церкв св. митрія (1877).

3. овгопілля - церкв св. митрія т дзвіниця (поч ток

4. иселиці-церкв св. рійці (1861-1877).

5. онятин - церкв св. силія і дзвіниця (1977).

6. риничі-церкв св. имеон товпник (1878).

7. лоск -церкв св. етр і вл т дзвіниця ( ст.).

8. озтоки - спенськ церкв і дзвіниця (1846).

9. елятин - реко-к толицьк церкв (друг половин ст.).

10. елятин - церкв іздв огородиці т дзвіниця ( $\mathrm{V}$ ст.).

11. тебні- спенськ церкв (кінець V ст.).

12. ор ки-церкв св. о нн рестителя (1872-1874).

13. сть- утил - церкв св. р скеви т дзвіниця (1878).

14. епіт-церкв св. ллі т дзвіниця (1898).

15. петки - вято- окровськ церкв т дзвіниця ( $\mathrm{V}$ ст.).

16. блуниця-церкв св. их їл і вриїл (1933). 
yзeї

1. узей-с диб . едькович (селище утил).

2. узей історії сел ергії (с. ергіï).

3. узей-с диб ук'ян обилиці (с. ергії, хутір р сний іл).

4. узей бойової сл ви (с. епіт, прикордонн 3 ст в ).

5. узей пис нки (с. блуниця, приміщення школи).

6. узей історії сел овгопілля (с. овгопілля, приміщення школи).

7. узей етногр фії (с. ідз х ричі).

8. узей мистецьких робіт сенії олотило (с. ідз х ричі).

9. узей “ к рби рідного сел " (с. риничі) [5].

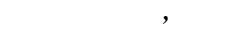

ірське ко - м льовниче гірське озеро природного походження поблизу с. ижній лівець епітської сільської р ди утильського р-ну.

ергіївськ мінер льн вод - с. ергії утильського р-ну. лоридно-к льцієвон трієвого скл ду мінер льн вод .

К м'яніл бг чК . утильський р-н, с. сть- утил . ідкісний вип док форми звітрюв ння, пов'яз ний 3 н родною легендою. $є$ н укове т естетичне зн чення ( сть- утильськ сільськ р д ).

мінь “ б”, утильський р-н, с. риничі. риродне утворення в 3 пл ві p. еремош. є естетичне зн чення ( риничівськ сільськ $\mathrm{p}$ д ).

ечер овбуш . утильський р-н, с. ідз х ричі. м’ятк природи, пов'яз н з іменем легенд рного опришк лекси овбуш . є історичне зн чення.

келя “ мінь овбуш ”, утильський р-н, с. ідз х ричі. еологічн п м'ятк природи, пов’яз н 3 н родною легендою. $є$ естетичне зн чення.

келя “" ротяте к міння”, утильський р-н, с. ідз х ричі. ідкісний вип док вітрової ерозії. є н укове т естетичне зн чення.

одосп д ісків. утильський р-н, с. ісків ( риничівськ сільськ р д ).

одосп д уч вський, утильський р-н, с. епіт.

повідне урочище “ ов рниця”, у утильський р-н, с. озтоки. мереково-ялицевобукові пр ліси віком 170 років.

тері льно-технічн 6 з у утильському р-ні скл д ється з туристично-рекре ційних 6 3, з кл дів х рчув ння, гроосель сільського зеленого туризму (т бл. 3, 4).

p йоні ведуть будівництво близько 30 об’єктів, орієнтов них н сферу сільського зеленого туризму.

блиця 3

уристичн іх рчов 63

\begin{tabular}{|c|c|c|}
\hline кл Д & $\begin{array}{l}\text { ісце зн ходження } \\
\text { ( дрес ) }\end{array}$ & $\begin{array}{c}\text { ослуги, які н ються } \\
\text { (кількість ліжко-місць } \\
\text { у готелі т пос дочних } \\
\text { місць у рестор ні) }\end{array}$ \\
\hline $\begin{array}{l}\text { іжн родний туристичний } \\
\text { комплекс “ ' імчич” }\end{array}$ & ідз х ричі & отель - 30 \\
\hline уристичний комплекс “ устун” & $\begin{array}{c}\text { устун } \\
\text { ( лосківськ сільськ } \text { р д ) }\end{array}$ & отель - 12 \\
\hline $\begin{array}{l}\text { ідпочинковий комплекс “ утір } \\
\text { тихий” }\end{array}$ & ергіï & отель -26 , рестор н -50 \\
\hline
\end{tabular}




\begin{tabular}{|c|c|c|}
\hline отель-рестор н " ск p" & утил & отель - 12 , рестор н - 250 \\
\hline отель-рестор н “ літ” & утил & отель - 8, рестор н - 170 \\
\hline отель-рестор н “ ісов полян " & утил & отель -16, рестор н - 120 \\
\hline отель-рестор н “ дельвейс" & утил & отель - 14 , рестор н - 100 \\
\hline отель-рестор н “ вітл н ” & иселиці & отель -8, рестор н - 80 \\
\hline уристичний комплекс “ мпері л” & овгопілля & естор н -250 \\
\hline естор н-готель & озтоки & естор н - 200, готель - 12 \\
\hline ідпочинковий комплекс & риничі & $\begin{array}{c}\text { отель }-15, \text { їд льня }-30, \\
\text { с ун }-8 \\
\end{array}$ \\
\hline естор н " орянк" & утил & естор н - 120 \\
\hline олиб -б p “" лекси” & утил & 35 \\
\hline ун $-6 \mathrm{p}$ & утил & 6 \\
\hline
\end{tabular}

грооселі сільського зеленого туризму

\begin{tabular}{|c|c|c|c|}
\hline $\begin{array}{c}\text { б’єкти сільсь- } \\
\text { кого зеленого } \\
\text { туризму }\end{array}$ & ісцезн ходження & елефон & ерівник \\
\hline рив тн с диб & $\begin{array}{l}\text { іжброди ( ідз х ри- } \\
\text { чівськ сільськ р ди) }\end{array}$ & (03738) 2-83-73 & $\begin{array}{l}\begin{array}{l}\text { питко росл в сильо- } \\
\text { вич }\end{array} \\
\end{array}$ \\
\hline рив тн с диб & ідз х ричі & (03738) 2-83-41 & $\begin{array}{l}\text { л фівк силь сильо- } \\
\text { вич }\end{array}$ \\
\hline рив тн с диб & $\begin{array}{l}\text { орови ( ідз х ричів- } \\
\text { ськ сільськ р д ) }\end{array}$ & (03738) 2-83-62 & ойчук гор олодимирович \\
\hline рив тн с диб & озтоки & $\begin{array}{l}03738) 2-54-94 \\
0673721399\end{array}$ & ойчук еонід рійович \\
\hline рив тн с диб & Озтоки & 0969580279 & рія етрівн \\
\hline рив тн с диб & озтоки & (03738) 2-54-05 & силин в нівн \\
\hline рив тн с диб & озтоки & \begin{tabular}{|l|l|}
0506526302 \\
0673729980 \\
\end{tabular} & ків’юк лексій в нович \\
\hline $\begin{array}{l}\text { рив тн с диб } \\
\text { “ еремош”" }\end{array}$ & $\begin{array}{l}\text { петки } \\
\text { ( сть- утильськ } \\
\text { сільськ р д ) }\end{array}$ & 0972451294 & рій их йлович \\
\hline рив тн с диб & $\begin{array}{l}\text { тебні ( овгопільськ } \\
\text { сільськ р д ) }\end{array}$ & (03738) 2-86-46 & вло $\quad$ н сійович \\
\hline рив тн с диб & онятин & 0978883887 & иниця ристин ріївн \\
\hline рив тн с диб & иселиці & (03738) 2-22-87 & ечул ін н толіївн \\
\hline рив тн с диб & иселиці & $\begin{array}{l}(03738) \text { 2-61-19, } \\
098612-93-63\end{array}$ & рійович \\
\hline рив тн с диб & $\begin{array}{l}\text { ор ки ( иселицьк } \\
\text { сільськ р д ) }\end{array}$ & (03738) 2-20-03 & с рюк іктор едорович \\
\hline рив тн с диб & утил & \begin{tabular}{|l|}
$(03738) 2-10-42$ \\
\end{tabular} & льчук лекс ндр еонович \\
\hline рив тн с диб & $\begin{array}{l}\text { робище ( иселицьк } \\
\text { сільськ р д ) }\end{array}$ & (03738) 2-10-90 & он рх ергій в нович \\
\hline рив тн с диб & ергіï & 0964644687 & $\begin{array}{l}\text { б лик силин митрів- } \\
\text { н }\end{array}$ \\
\hline рив тн с диб & елятин & (03738) 2-34-36 & $\begin{array}{lll}\text { кіпор в нн } & \text { икол ївн } \\
\end{array}$ \\
\hline
\end{tabular}


рив бливими для гостей з вжди є тр диційні свят, фестив лі. р диційні свят p йону: гуцульське свято виходу н полонину “ олонинськ в тр ”, яке проводять щороку в ост нню неділю тр вня; етногр фічний фестив ль фольклору і гумору “ х рецький г рчик” (проводять щороку у третю неділю вересня), літер турномистецьке свято “ овков косиця” (проводять у першу неділю серпня).

еред елементів інформ ційної інфр структури н звемо путівник утильського р-ну, т кож рекл мні щити з інформ цією про основні туристичні с диби т туристичні комплекси. собливо н голосимо н існув нні туристичного с йту утильського p-ну ернівецької обл. “ утил туристичн ” (http://www.putyla.cv.ua/).

г лом є низк чинників, з вдяки яким утильщин утвердил сь серед інших р йонів кр їнських рп т як прив блив для розвитку вітчизняного т міжн родного туризму, зокрем т кі:

- відд леність р йону від великих міст т промислових центрів регіону;

- відсутність у с мому р йоні виробничих підприємств, які 6 з бруднюв ли н вколишнє середовище;

- межув ння р йону з м лон селеними і екологічно чистими гірськими територіями умунії т в но- р нківщини;

- різновид нез йм них діяльністю людини гірських л ндш фтів, х р ктерних для уковинських рп т;

- н явність великої кількості джерел мінер льної води з унік льними лікув льними вл стивостями;

- неповторний світ флори, більшість предст вників якого м $є$ ендемічне т реліктове походження і в кр їні більше ніде не поширен ;

- дивовижний світ ф уни, х р ктерний тільки для рп т;

- сприятливий клім т з м'якими сніжними зим ми, помірно вологим не спекотним літом т теплою сухою осінню;

- численні гірські ріки й потоки з к ск д ми водосп дів;

- piчк еремош, як один з кр щих об'єктів водного спортивного туризму в кр їні; - природні б г тств гірських лісів і полонин: гриби, ягоди т лік рські рослини;

- легенд рне гірське озеро уковинське око-єдине в уковинських рп т х;

- порівняно зручне втотр нспортне сполучення;

- н явність туристських з кл дів т мережі сільських с диб зеленого туризму;

- гірськолижні схили т послуги кв ліфіков них інструкторів-гірськолижників;

- $з$ тишні гірські поселення, розт шов ні в розлогих міжгірських улоговин х;

- м тері льн і духовн культур гуцулів, тр диційні щорічні уцульські фестив лі “ имові з б ви”, “ вято полонинської в три”, “ овков осиця” т інші фольклорноетногр фічні дійств ; оригін льні гуцульські вироби н родних умільців з дерев , мет лу, шкіри, глини, вовни, вишивк, пис нк рство; своєрідн т см чн гуцульськ кухня;

- н явність цінних рхітектурних т історичних п м'яток (дерев'яних церков, музеїв, житлових будівель тощо).

роте головне з вд ння, що стоїть перед дміністр тивними т прив тними структур ми р йону - ре ліз ція рогр ми розвитку туризму в утильському $\mathrm{p}$ йоні н 2012-2015 роки.

добутки р йону в н прямі розвитку туризму ще д лекі від б ж них, вони х р ктеризують лише поч ток великої роботи в цій ц рині, просув ння якої з лежить від успішного вирішення низки проблем. окрем , до чинників, що стримують сьогодні розвиток туризму в р йоні, н лежить: 
- недост тність методичної, орг ніз ційної, інформ ційної підтримки суб'єктів туристичної діяльності;

- низьк якість доріг, відт к скл дність у з лученні потужних, серйозних інвесторів;

- недост тність з безпеченості втомобільних доріг туристичною, сервісною структурою (нем єдиної системи м ркув ння втошляхів до з кл дів туризму, у тім числі сільського зеленого);

- низький рівень розвитку рекре ційно-туристичної інфр структури (проблем водопост ч ння, к н ліз ції н селених пунктів, розвиток служби зв'язку т комунік цій, функціонув ння служб сервісу, гром дського х рчув ння т побутового обслуговув ння);

- нерозвиненість готельного господ рств ;

- недост тність якості т сортименту туристичних послуг;

- відсутність н лежного бл гоустрою берегів річок і водоймищ для туристичних потреб (м ло обл дн них місць відпочинку, гірських притулків тощо);

- сл бк орг ніз ція культурно-розв ж льного обслуговув ння;

- сл бк систем інформ ційного з безпечення, рекл мної інформ ції про р йон (вст новлення рекл мних щитів, випуск туристичних к рт т буклетів, створення єдиної системи зн кув ння);

- проблемою з лиш ється т кож координ ція роботи з орг ніз ції туризму в р йоні. спішн ре ліз ція стр тегії ст лого розвитку утильщини зн чно з лежить від умов ктивної співпр ці місцевої вл ди, підприємницького й ділового середовищ , гром дських структур т орг ніз цій, ктивності територі льної гром ди.

тже, з ур хув нням того, що рекре ційно-туристичний потенці л території утильського р-ну ернівецької обл. дост тньо високий в бсолютних т відносних пок зник х порівняно з іншими дміністр тивними р йон ми ернівецької обл., проте його не використовують повною мірою, то м ксим льне використ ння приведе до оптиміз ції ст новлення т потенційного розвитку туристичного бізнесу. е відбув тиметься через призму розвитку т ких видів туризму, як екологічний, сільський зелений, історико-культурний, пізн в льний, спортивно-оздоровчий, мисливський.

1. ейдик . екре ційно-туристські ресурси кр їни. етодологія т методи н лізу, термінологія, p йонув ння : [моногр фія] / . ейдик. - . : ид вничополігр фічний центр “ иївський університет”, 2001. - 395 с.

2. чевський . озвиток рекре ційної сфери в рп тському регіоні / . чевський, . вінцов, . узнєцов // кр. б льнеол. журн. - 2001. - № 1. 99-104.

3. зур . оці льно-економічні умови розвитку рекре ційної індустрії (н прикл ді рп тського регіону) : [н вч. посібник] / . зур. - . : ентр н вч льної літер тури, 2005. - 96 с.

4. уково-методичні з с ди реформув ння рекре ційної сфери / . . р вців, . . ринів, . . оп ч, . . узик. - ьвів : кр їни, 1999. - 78 с.

5. http://www.putyla.cv.ua/

6. http://www.oda.cv.ua/ 


\title{
FACTOR AND RESOURCE PRECONDITIONS OF TOURISM ORGANIZATION IN PUTYLSKYI DISTRICT OF CHERNIVTSI REGION
}

\author{
Pavlo Romaniv, Andriy Man'ko \\ Ivan Franko National University of Lviv, \\ P. Doroshenko Str., 41, UA - 79000 Lviv, Ukraine
}

\begin{abstract}
Factors of tourism development in Putylskyi district of Chernivtsi region were investigated. Tourism resources, infrastructure, material and technical bases of district for the purposes of tourism development were studied. The impact of natural, geographical, historical, cultural, socio-economic conditions and the factors that potentially and actually influence on the formation of regional tourism product of the study area were defined. Factors that limit the development of tourism in the district, particularly low level of recreation and tourism infrastructure and lack of methodical, organizational and information support of subject of tourist activity were traced.
\end{abstract}

Key words: Putylskyi district, tourism resources, infrastructure, tourism organization.

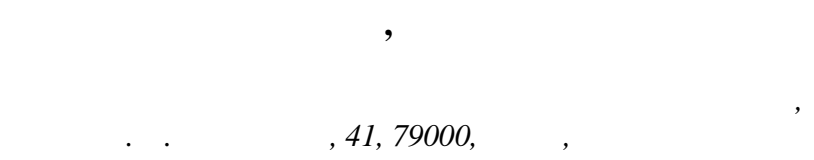

рослежено ф кторы р звития туристической отр сли утильского р-н ерновицкой обл. сследов но туристические ресурсы, инфр структуру и м тери льно-техническую б зу р йон для нужд р звития туризм . ыявлено влияние природно-геогр фических, историко-культурных, соци льно-экономических условий и ф кторов, которые потенци льно и кту льно влияют н формиров ние регион льного туристического продукт исследуемого $\mathrm{p}$ йон . рослежено лимитирующие ф кторы р звития туризм в $\mathrm{p}$ йоне, в ч стности низкий уровень $\mathrm{p}$ звития рекре ционно-туристической инфр структуры и недост точность методической, орг низ ционной, информ ционной поддержки субъектов туристической деятельности.

лючевые слов : утильский р йон, туристические ресурсы, инфр структур, орг низ ция туризм . 